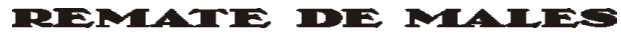

Campinas-SP, v.38, n.2, pp. 1083-1106, jul./dez. 2018

\title{
Na PRESEnça de HANS UlRich GUMBRECHT: UMA ENTREVISTA ${ }^{1}$
}

\author{
Luciana Molina Queiroz ${ }^{2}$
}

A entrevista se deu em uma manhã de quinta-feira nublada, no dia 15 de março de 2018, no escritório que o professor Gumbrecht tem na Universidade de Stanford. Conversamos durante cerca de 1 hora e 40 minutos. No mesmo dia, horas mais tarde, seria realizada em um auditório lotado sua última aula na universidade antes de sua aposentadoria. Após a aula, e com a sua vivacidade habitual, ele comandaria ainda - quase como se postergasse sua despedida de Stanford - uma seção de comentários sobre as touradas espanholas. Na entrevista, tanto as perguntas como a maior parte das respostas foram realizadas em português, mas certos termos, expressões e frases foram enunciados em outras línguas, e optei por mantê-los no original nos momentos em que me pareceram ter importância expressiva ou estilística, ou, ainda, quando se tratava de algum conceito ou terminologia filosóficos. O tom coloquial das respostas foi, em geral, mantido, com algumas adaptações que se fizeram necessárias para uma melhor compreensão do texto em sua forma escrita.

1 Esta entrevista com o professor Hans Ulrich Gumbrecht foi realizada no último mês do winter quarter [trimestre de inverno] e ao fim da minha visita à Universidade de Stanford, na Califórnia (EUA), na qual fiz doutorado sanduíche sob sua orientação e com apoio da Capes.

2 Mestra em Filosofia pela Universidade Federal de Minas Gerais - UFMG e doutora em Teoria e História Literária pela Unicamp, com bolsa do CNPq: <lucianamqueiroz@gmail. com>. 
1. Existe em seu trabalho uma poderosa crítica à interpretação que parece particularmente incompatível com a noção de close reading, do New Criticism - que é uma prática muito popular em departamentos de literatura de países anglófonos. Ao invés disso, temos a noção de "presença". O senhor diria que isso se deve a uma necessidade de situar histórica e materialmente a obra literária de uma forma que o New Criticism não faz? O senhor acredita que o New Criticism ainda tem atualidade e contribuições a fazer aos estudos literários?

Não estou negando de jeito nenhum que ler precisamente e ler com concentração e pensar no texto, e até de uma forma filológica, seja importante. É uma coisa que se pode melhorar nos estudos de literatura e nos estudos de ciências humanas em geral. É, como se fala em inglês, uma skill muito importante. Possivelmente tenho uma impressão mais forte disso hoje em dia, na idade eletrônica. Tenho a impressão, ao observar os graduandos de Stanford, de que são fantásticos identificando o que se chama em filosofia analítica de propositional content [conteúdo proposicional], o conteúdo do texto. Leem rapidamente e com uma concentração muito boa. Mas é muito difícil para eles captar a textura, o modo como o texto é feito, o lado retórico e até sintático, gramatical do texto. E, nesse sentido, tenho em primeiro lugar uma admiração muito grande pelo New Criticism. E, como disse, acho que é uma competência que qualquer pessoa deveria ter nas ciências humanas. Na área de história igualmente. A minha crítica é basicamente contra isso ser o projeto final e absoluto do que a gente está fazendo nos estudos literários. Trata-se antes de uma crítica a pressupostos da tradição hermenêutica, que não é idêntica ao New Criticism. Genealogicamente, a tradição hermenêutica é sobretudo alemã. Começou no século XVIII, XIX, sobretudo com a hermenêutica teológica, com alguém como Schleiermacher, por exemplo, que pressupunha que a tarefa básica e última dos estudos hermenêuticos é identificar um conteúdo proposicional, como fala a filosofia analítica, isto é, a partir do pressuposto de que cada texto tem um conteúdo objetivo e final. Outro pressuposto está mais relacionado ao que diziam os estudos da recepção, que buscavam atualizar o 
sentido do texto. Por exemplo, o que está fazendo o Robert Harrison ${ }^{3}$ na sua aula de Dante é o desenvolvimento de uma maneira de tentar ler Dante contemporaneamente. Acho essas abordagens mais que legítimas. Mas acho também que não são a tarefa final dos estudos literários. Eu até tenho muitas razões para ser contra, mas uma muito forte é que se trata de um abuso da autoridade do professor de literatura, que se coloca como se tivesse uma competência mais alta de identificar o conteúdo do texto. Isto é, sou contra a ideia de que, se alguém afirma que o conteúdo de Grande Sertão é x, então ele tem que ser $\mathrm{x}$, o que reduz a liberdade do leitor de fazer com o texto qualquer coisa que ele gostaria de fazer.

2. Gostaria de saber como o senhor avalia sua relação (ou mesmo filiação) com as tradições existencialista e fenomenológica na filosofia. Sua capacidade de dar vivacidade e fundo históricos aos objetos examinados é notável. No entanto, gostaria de saber o que o senhor pensa a respeito da possibilidade sugerida por essas tradições de se chegar a conceitos meta-históricos.

Fenomenologia é um daqueles conceitos que a gente não sabe muito bem o que quer dizer. Existe uma compreensão, baseada na fenomenologia com "f" maiúsculo, que remonta à obra de Husserl e Bergson. Mas também se fala de fenomenologia em um sentido mais geral como um jeito, um estilo filosófico, que se concentra nos fenômenos. Isto é, no autodesvelamento, falando heideggerianamente, do caráter dos fenômenos. Para usar uma frase de que gosta o Robert Harrison, trata-se do envolvimento com o fenômeno se mostrando. Essa é, afinal, a semântica histórica do conceito: o fenômeno é uma coisa que se mostra. Descrever coisas é, para mim, mais importante que interpretação, assim como ter certa proximidade com os fenômenos, no sentido de tangibilidade [palpability]. E eu muitas vezes ouço as pessoas falando que meu jeito e meu estilo são muito fenomenológicos. E concordo. Não é um problema nesse sentido. Por exemplo, acho importante a possibilidade de descrever bem uma lata

3 "O autor faz aqui referência ao professor Robert Pogue Harrison, especialista nos estudos de Dante Alighieri, e professor do departamento de French and Italian da Stanford University. Além de seu amigo próximo, o Harrison esteve à frente, juntamente com Gumbrecht, do grupo de estudos de filosofia (Philosophical Reading Group) em Stanford, também conhecido como PRG. Harrison será citado novamente em outros momentos desta entrevista." 
de Coca-Cola. Foi aqui no colóquio ${ }^{4}$ que dissemos que eu faço muitas abstrações, que estou obcecado com detalhes. Acho que esse é também meu lado fenomenológico. Tenho, nesse sentido, uma proximidade com o escritor francês Francis Ponge. Não o acho um grandissíssimo autor, mas ele descreve aquelas coisas pequenas. E eu me aproximo disso. Há também uma segunda relação mais genealógica com a fenomenologia husserliana. Em 1971 foi publicado o livro A construção social da realidade, de autoria de dois sociólogos, Berger e Luckmann, e é desse livro que vem basicamente o termo construtivismo. Luckmann e Berger eram alunos de um filósofo e sociólogo austríaco em migração, Alfred Schulz, que, por sua vez, foi aluno do Husserl. E o Luckmann foi meu professor de sociologia. Uma sociologia não empírica, bem filosófica, em Konstanz [cidade da Alemanha]. Então eu poderia dizer que tenho uma relação familiar via Luckmann e Schulz ao Husserl e à fenomenologia. O que seria a base da fenomenologia? O projeto de Husserl foi o de poder descrever com precisão jamais vista antes as estruturas gerais da mente, da consciência humana. Para então poder dizer que qualquer percepção que a gente tem sempre está filtrada pela mente humana. Com isso, chegamos a uma definição de consciência e, depois, a uma definição de realidade. Esse projeto de Husserl foi abandonado nos anos 1920, 1930. E o que sobreviveu foi a construção da consciência humana. Passamos a adotar o construtivismo a partir da percepção de que não é possível chegar à realidade última. Dentre as escolas filosóficas da minha tradição intelectual primária, alemã, aquela que mais me formou e me impressionou foi aquela fenomenologia. Ainda que hoje eu tenha um interesse maior pelo realismo, com " $\mathrm{r}$ " maiúsculo, isto é, Realismo filosófico em plena consciência da sua impossibilidade, eu diria. O livro Produção de presença, por exemplo, é isso. Mas, reiterando, fenomenologia nos dois sentidos da palavra é importante para mim. No primeiro sentido, de uma forma mais programática e espontânea. O segundo, em relação com aquela escola do Thomas Luckmann, o qual era, na verdade, esloveno e faleceu recentemente.

Com o existencialismo tenho uma relação biográfica diferente. Quando eu estava no ensino médio, e nos primeiros anos na universidade, aquele existencialismo sobretudo da metade do século XX francês, Camus, Sartre etc., era a filosofia dominante. Naquela época, Foucault, e mesmo

4 Trata-se do colóquio After 1967: Methods and Moods in Literary Studies, realizado na Stanford University, em homenagem ao professor Gumbrecht, nos dias 9 e 10 de fevereiro de 2018. 
Derrida, já tinham começado a publicar, mas ninguém sabia nada sobre eles. Como aluno de ensino médio, participei de uma competição que tinha um prêmio e escrevi um ensaio sobre Jean-Paul Sartre e o marxismo, no qual eu argumentava que o filósofo existencialista era "realmente" marxista. E ganhei um prêmio de consolação. Esse existencialismo primário era quase água para aprender a nadar, mas de repente se tornou uma vergonha ser existencialista, porque se tinha a obrigação de ser marxista. O Existencialismo passou a ser visto como uma coisa subjetiva, individualista, burguesa, e, portanto, horrível. Também na França Sartre de repente perdeu toda a autoridade e prestígio. Passou a ser visto como tão terrível que o Derrida nunca o menciona, por exemplo. Eu lembro que o professor catedrático que me deu o primeiro emprego gostava de Camus e nunca o mencionava. Hoje em dia estou usando bastante o conceito, o nome existencialismo, por duas razões. Uma razão você vê no seminário, ${ }^{5}$ que tem um jeito existencialista, o bliss: o que estou fazendo filosoficamente é um esforço de fazer descrições de estruturas de condições gerais da vida individual. O fenômeno em si pode acontecer com todo mundo. Claro, estamos perguntando também se bliss tem uma dimensão social. Mas, fundamentalmente, são coisas não individuais no sentido de que todo mundo pode ter na sua vida individual um sentido de bliss. Em segundo lugar, por razões menos filosóficas, eu diria também que tenho sempre ceticismo com a noção de que é preciso ser muito político. Se você quer ser tão político, então por que escolheu essa profissão nas ciências humanas? Trata-se de uma profissão mais longe da política real que praticamente qualquer outra profissão. E eu também não tenho nada contra políticos. Sendo cidadão americano, poderia participar em um protesto contra Trump. Não o estou fazendo por falta de tempo. No mise au point da aula de hoje tem até certos political statements [posicionamentos políticos]. No seminário saiu naturalmente, com toda a discussão sobre o Silicon Valley [Vale do Silício]. Assim, posso muito bem fazer um comentário político. Só não acho que é obrigatório fazêlo. Nesse sentido, e isso diz muito sobre o que penso do tema ensino, posso dizer que não quero ser o professor que a cada seminário emancipa 2 bilhões de pessoas não privilegiadas. Essas pessoas não privilegiadas

$5 \mathrm{O}$ autor está se referindo à disciplina que estava ministrando em Stanford à época, Literature and Bliss, na qual a proposta era investigar a existência de uma relação constitutiva entre bliss e literatura. A palavra inglesa bliss poderia ser traduzida de maneira aproximada como "felicidade", "êxtase" ou, ainda, "bem-aventurança". 
não têm ideia do que eu estou fazendo na universidade. Estou satisfeito se eu, a cada ano como profissional, puder dizer ao fim que talvez tenha sido importante para 20 ou 25 alunos, para ter despertado neles uma vida intelectual independente. Um cara como Sam, ${ }^{6}$ por exemplo. Estou super orgulhoso dele, mesmo não compreendendo nada do que ele está fazendo lá no writing code [programação] em computer science [ciência da computação]. Mas que ele saiba falar sobre o Musil no seminário e que seja capaz de usar o Heidegger para explicar o que está fazendo quando está programando, é uma coisa linda. Ontem ditei a carta para você para a Capes. Então estou imaginando. Espero que tenha sido um tempo bom para você. Não só no sentido de having a good time. Isso também. Espero que o tempo aqui também tenha sido, talvez não útil, porque não gosto de "útil" nas ciências humanas. Mas um tempo produtivo e ativo, com desafios e tudo o mais. Na práxis da minha profissão, por exemplo, também há a estrutura do office hours. ${ }^{7}$ Às terças eu falo com 23 pessoas individualmente, por meia hora cada uma. E estou gostando muito. Acho que isso tem uma utilidade e justifica o meu salário. Quanto à liberação de todos os oprimidos do mundo, não ajuda a ninguém, isto é, não ajudaria ninguém a tentativa de liberação na minha aula. Um político tentando isso ajuda muito. Só para que não haja mal-entendido: eu não estou dizendo que sou contra a política, ou mesmo que não tenho uma opinião, uma posição política. Mas acho que impor minha posição política, por maravilhosa que seja, numa aula, é um abuso. A mesma coisa ocorre com um professor de ciência política, que deve cultivar com seus alunos uma competência de fazer política. Nossos alunos sempre falam bem da Condoleezza Rice nesse sentido. Ela é republicana, de direita, mas dizem que suas aulas são maravilhosas e que todo mundo pode aprender.

3. Sabe-se que Heidegger é uma influência importante no seu trabalho. Dentre outras razões, pela importância do conceito de Stimmung. A minha impressão, contudo, é que o senhor aperfeiçoou o conceito e trouxe para ele e para os estudos literários concretude e vivacidade que o próprio Heidegger não alcançava ao

\footnotetext{
6 Trata-se do aluno de graduação Sam Ginn, de quem Gumbrecht é supervisor, e que apresentou um seminário sobre o romance $O$ homem sem qualidades, de Robert Musil, na disciplina que o entrevistado ministrava durante aquele período. O aluno está se graduando na Stanford University em Literatura Comparada e Ciência da Computação. 7 Neste caso, trata-se de horas no escritório dedicadas ao atendimento individual de alunos.
} 
analisar obras de arte. Poderíamos citar, por exemplo, $\boldsymbol{A}$ origem $\mathrm{da}$ obra de arte. Apesar dos esforços que empreende, ele leva a cabo nessa obra uma discussão que me parece extremamente abstrata e generalizante, não nos possibilitando vir a conhecer a qualidade de cada Stimmung. Quando leio seus textos sobre arte e literatura, professor, tenho a impressão de que sou capaz de me reconectar às obras. Os seus textos trazem a presença da obra novamente, como se eu estivesse efetivamente relendo o livro ou contemplando a pintura. Nesse sentido, os textos parecem ser uma continuidade sensível da obra. $O$ senhor tinha isso em mente quando iniciou essa linha de investigações, isto é, mais precisamente, que estaria dando uma contribuição para além de Heidegger?

Como fala meu amigo Robert Harrison, eu tenho confiança intelectual no Heidegger. Heidegger biograficamente é horrível. Só para você, ou talvez para a entrevista também, posso dizer que, até chegar aqui em Stanford, aos 41 anos, tinha conseguido não ler uma palavra dele, porque achava que deveria ser possível ter uma vida intelectual boa sem os ex-nazistas. Chegandoaqui, duas coisas me fizeram reconsiderara decisão. Todo mundo estava com expectativa de que eu soubesse muito do Heidegger, quando eu não sabia absolutamente nada. E, segundo, a distância geográfica e cultural. Pensei que, talvez, não estando na Alemanha, seria outra coisa ler Heidegger. E tudo bem. Agora, estou fazendo muitas coisas com Heidegger: o conceito do desvelamento do ser, o conceito de serenidade, Gelassenheit. São coisas ativamente importantes para mim. As vinte páginas sobre Stimmung, de Ser e tempo, são as coisas não importantes dele. O autor fala de Stimmung no sentido central de Geworfenheit, que quer dizer que você está lançado na existência sem você escolher. Uma famosa coisa que Kant dizia está relacionada com isso. Quando os bebês nascem, dão um grito ao nascer, para respirar. Para Kant, isso se dava como maneira de protestar por ninguém lhes ter perguntado se queriam viver. Essa descrição até funciona. Mas acho que é uma descrição no sentido literal comparativamente chata, que não tem muita plasticidade ou complexidade. Ele [Heidegger] precisa disso para dizer que existem coisas na existência humana, no Dasein, que a gente acha que não escolhe. Então quase discordo de Heidegger sobre Dasein. Nos anos 1920, o conceito tinha um certo fascínio, uma certa popularidade, e Heidegger talvez tenha parte nisso, mas não tem nada importante nem novo no que ele faz. Isso me interessava historicamente porque, se existe uma dimensão estética 
subestimada, e talvez mais estritamente na crítica literária, e não na área de história, é Stimmung. Não estou dizendo que Stimmung é tudo, e maravilhoso. Mas vou dar um exemplo brasileiro. Você realmente não vai ler Grande sertão pelo plot, pelo enredo. Até tem um plot bastante bacana, porque tem aquela surpresa grande no final. Meu exemplo preferido, que já falei na aula: a única pessoa que já encontrei que estava lendo Morte em Veneza segundo o plot foi minha mãe, que, tendo lido a metade da novela, disse: "Aschenbach e Tadzio ficarão juntos no final". Eu falei: "Mãe, você sabe que este livro, esta narrativa, começa com uma descrição de um tempo específico pré-alpino, um tempo em que todo mundo tem dor de cabeça e fica deprimido. Uma narrativa que começa assim não pode levar a um casamento no fim, sobretudo entre homossexuais". Quer dizer que você lê uma coisa como Morte em Veneza pela imersão numa Stimmung. Acho que, sobretudo na literatura narrativa do século XX, Stimmung é muito central. Existia aquela impressão, de pós-Segunda Guerra Mundial na Europa, de que Stimmung já tinha acabado porque eles associavam o conceito com harmonia. Nesse sentido, existe um ensaio maravilhoso do Leo Spitzer, publicado nos primeiros anos da Segunda Guerra Mundial, sobre a história do conceito de harmonia, em que ele fala muito de Stimmung. Para ele, agora, após o que aconteceu, não se poderia voltar a Stimmung. Com a desconstrução, Stimmung passa a ser considerado um horror, porque não é textual e é visto como ontológico. O mesmo se dá na melhor história conceitual que existe. David Wellbery, chega a dizer que o conceito já acabou e nunca poderá ser reciclado. Mas, ao mesmo tempo, apesar de todas essas quase condenações do conceito, acho que na literatura do século XX ele é muito central. Eu diria isso a respeito de todos os cânones, de todos os Grandes Sertões de cada nação. À la recherche du temps perdu, O homem sem qualidades, Ulisses. Acho que a dimensão estética central é Stimmung. O sabor daquela alta burguesia meio aristocrática francesa entre Paris e Normandie. O momento, um ano antes do começo da Segunda Guerra Mundial, de uma Viena maravilhosamente decadente. O sabor de um só dia em Dublin nos anos 1920. Eu adoro dizer que não tem plot, e sim, episódios. Você poderia perguntar se a Agathe e o Ulrich, personagens de $O$ homem sem qualidades, vão voltar no final das contas. Mas na verdade essa pergunta não é realmente interessante. É o que eu gostaria de sublinhar com o meu trabalho. Não tinha, é claro, intenção de desenvolver isso programaticamente, mas, depois que comecei a me interessar por Stimmung, descobri que seria possível dizer 
que há uma dimensão de presença. Para fechar e fazer outra nota ao pé da página, a coerência da minha obra escrita é muito menos programática e intencional do que parece.

4. Um dos aspectos que considero mais interessantes no seu trabalho é o fato de ele ser animado por duas questões muito distintas, porém complementares: ele valoriza a dimensão do corpóreo e sensorial na lida com objetos, e, no entanto, na obra "Nosso amplo presente", o senhor nos mostra que a cultura tecnológica de hoje leva a valorizar cada vez menos a presença física. Podemos pensar essas questões à luz de alguns objetos já conhecidos, como os produtos desenvolvidos pela Apple que valorizam o toque ou jogos como o Nintendo Wii, que estimulam que se faça atividade física dentro de casa, ou ainda os cinemas $3 \mathrm{D}$ e $4 \mathrm{D}$, que buscam ampliar os estímulos físicos sentidos pelo receptor. Quando observamos as obras de ficção científica mais contemporâneas, não raro visualizamos nelas um futuro em que a realidade virtual será tão bem desenvolvida que poderá ser confundida com a "realidade" em sentido estrito. $O$ que eu gostaria de saber é se o senhor considera que a cultura tecnológica é fundamentalmente uma cultura de esquecimento do corpo, ou se o senhor vê nela uma possível outra relação com o corpo, que traz experiências igualmente interessantes?

O paleontólogo francês André Leroi-Gourhan entendia que a cultura humana é a prolongação da evolução biológica do homo sapiens. Sua evolução física e biológica é acelerada com a cultura, que, por sua vez, é acelerada inacreditavelmente pela tecnologia. Pode-se dizer, por exemplo, que, com um celular como o iPhone, são vários os órgãos que uma pessoa adquire. Sua voz chega mais longe, há uma visão de coisas que não estão na sua presença etc. Então, nesse sentido, poderíamos dizer que, não qualquer tecnologia, mas especificamente a tecnologia eletrônica tem um efeito não de reduzir, mas de eliminar o espaço. Um celular pode estar completamente onipresente, no sentido do predicativo "divino". Em tempo real você pode estar conectada com sua mãe no Espírito Santo, como se não estivesse a não sei quantos quilômetros de distância. O espaço, dessa forma, é completamente eliminado. Tanto Kant como Husserl diriam que o que a gente chama de espaço é a dimensão existencial que está se desenvolvendo ao redor do corpo. Eliminação do espaço é, então, eliminação do corpo. E eu estou quase certo de que esse 
desejo do corpo, tanto a práxis diária - por exemplo, de pessoas fazendo dieta, pessoas fazendo jogging na praia etc. -, como a teórica - a partir da famosa recuperação do corpo nas ciências humanas - são reações a essa perda existencial. A importância dos esportes está relacionada a isso. $\mathrm{O}$ meu fascínio por isso começou, creio, nos anos 1980. Antes disso eu era ingênuo e fazia parte desse desinteresse pelo corpo.

Posso dar outro exemplo. Recentemente, eu e minha esposa estivemos em um restaurante com amigos alemães que têm dois meninos, um de cinco e o outro de três anos. Estavam conosco no restaurante e ficavam silenciosos, se comportavam muito bem. Estavam com seus celulares jogando jogos para crianças. É notável que, com esses celulares, há uma ativação das mãos fantástica. Então existe, quase no sentido de Foucault, um micropoder que não elimina o corpo. $\mathrm{Eu}$, por exemplo, quanto ao celular, nem imagino como as pessoas podem fazer isso. Até com o teclado que tenho no escritório cometo um monte de erros quando estou escrevendo. Então acho que isso é uma das grandes ondas existenciais e epistemológicas que estamos observando como reação. Ao mesmo tempo, eu diria que o cotidiano hoje pode ser descrito como o universo de contingência. Quer dizer, apesar de toda a crítica política, o horizonte de escolhas que cada pessoa - nem sequer muito privilegiada - tem, em vez de estar sujeito a um ritual, uma necessidade e uma impossibilidade, ele é quase indefinido. Estava dizendo hoje, brincando, que os jovens precisam de quinta inteira e metade da sexta para preparar o fim de semana, para escolher tudo o que é possível escolher. E, nesse sentido, acho que também existe um desejo de pertinência, de necessidade e de se prender a alguma coisa [to hold on something]. Então eu diria que realmente o cruzamento e a convergência desses dois desejos muito básicos, desejo de corporalidade e de concretude, de um lado, e desejo de pertinência, de não contingência, de outro lado, existem, pois os dois conceitos são semelhantes, no entanto, eles não são idênticos. Eu acho que isso explica o que está acontecendo na cultura de hoje nesse sentido. Para concluir, o grande descobrimento do Steve Jobs foi que a tecnologia eletrônica vende melhor e quase ocupa um status diferente, se os objetos são feitos com uma certa estética, isto é, sobretudo se eles despertam a vontade de serem tocados. Da mesma forma funciona toda aquela coisa do mouse, de mover, de touch screen. Meu amigo Friedrich Kittler era muito purista nesse sentido. Ele nunca teve um computador com touch screen, pois achava que se tratava da perda da inteligência eletrônica. De certa forma acho que a reação dele foi 
adequada porque o contato físico com a máquina engendra uma espécie de comprometimento. Comprei recentemente um Tesla, um carro que funciona bastante com a voz. Uma funcionária perguntou: "Você já elegeu um nome para o seu carro?". Achei a ideia horrível e de mau gosto, uma coisa que se fazia bastante nos anos 1940 ou 1950. Mas depois descobri que é mesmo necessário dar um nome pra ele, porque senão o carro reage a conversas que você tem no interior dele. Então a gente o chamou de carro, car. "Car, can you please do this and this?" Então ao mesmo tempo vemos uma eliminação completa do espaço e uma certa volta disso. Uma grande tangibilidade, não no Silicon Valley, como produtora de software, mas na venda dos objetos, é importante. Essa foi a descoberta do Jobs, que não inventou nada, mas que assimilava todas as coisas. Isso é perceptível até no emblema da Apple, que sugere uma mordida.

5. Ainda sobre essa temática do corpo: a Estética surge como disciplina no século XVIII. Embora hoje seja possível entender que essa área da filosofia abarca questões tão diversas quanto a arte, os sentimentos e as sensações corporais etc., é interessante notar como muitas das reflexões sobre arte surgidas desde então se mantêm bastante "puritanas". O esforço de Kant em separar o belo das apetições sensíveis parece um projeto suspeito de ainda carregar esse desprezo cristão ou cartesiano pelo corpo. E, no entanto, $A$ crítica da faculdade do juízo, de Kant, é até o momento muito benquista, sobretudo no contexto das artes plásticas, o que eu pessoalmente considero extremamente inquietante. $O$ senhor acha que a interpretação acadêmica também compartilha desse fundo do esquecimento do corpóreo? Deveríamos, ao invés disso, valorizar mais os sentidos e os efeitos corporais nas investigações e pesquisas dentro da universidade?

O Kant é genial. Escreveu a estética talvez mais importante na história da filosofia. Contudo, o exemplo que Kant mais usa são wallpapers [papéis de parede]. Nas paredes da casa dele, só havia uma representação, o retrato do Rousseau. Mais especificamente, ficava no escritório, lá no fundo. Ao mesmo tempo, Kant, apesar do corpinho fraquinho, gostava de uma boa comida. Hoje em dia se fala em comer como algo que faz parte da experiência estética, mas, para ele, não era possível considerar assim. Para ficar perto do seu argumento, o que acho interessante, falando da plástica, da escultura, é que, na estética mais conceitual que existe, a de Hegel, o 
apogeu da História da Arte é a escultura clássica grega. Ele claramente gosta dela, assim como Winckelmann. Mas Hegel não sabe o que fazer com a escultura clássica grega. Então eu acho que sim, há um esquecimento do corpóreo. E vou dar um exemplo muito simples. De uma certa forma não só a crítica literária, mas as ciências humanas, a musicologia, a arte etc., sem que tenham feito disso um projeto, têm continuado essa tradição. Tudo vai se transformando em conteúdo proposicional. Daí minha resistência, meu ceticismo, em relação à interpretação. O exemplo que acho bom é o seguinte: se você lê as interpretações mais influentes de Baudelaire, talvez o poeta mais central na tradição moderna europeia, tais como as feitas por Paul de Man, Spitzer, ou por autores americanos etc., sabe que todos aqueles ensaios fantásticos, muito influentes, poderiam ser textos em prosa, que não falam em absoluto da prosódia. Às vezes dizem algo do soneto, mas não fazem nada com isso. Lembro que eu gostava, quando estava dando aulas sobre lírica, sobre poesia, de recitar. Por exemplo, dei uma aula sobre Hölderlin, e nenhum aluno falava alemão. Mas eu comecei aquela sessão lendo um poema bastante extenso de Hölderlin em alemão. O que busco é aquela presença incorporada do poema, que é de muito longe uma interpretação. É fazer conjurar a presença disso, ou seja, tratase de fazer uma coisa que tradicionalmente não se fazia na crítica literária. Qualquer cena erótica numa interpretação de literatura clássica vai se alegorizando. “O que quer dizer?” Não quer dizer nada. Como aquela coisa dos meus calouros que sempre citava, quando estava dando aquele curso sobre The Pleasures of Sex. Eu perguntava na segunda semana por que sexo é tão bom. E eles diziam: "Porque me ajuda a expressar o meu amor pela minha amiga, pela minha namorada”. É necessária uma linguagem muito mais prática. Como se poderia expressar uma frase relativa, um subjuntivo, sexualmente? Sexualmente não pode funcionar. Quer dizer, não quero falar sempre de presença, mas a tangibilidade é uma coisa que a gente deveria se esforçar mais em obter. Tenho falado que a profissão deveria se tornar mais dêitica. Por exemplo, hoje, no nosso seminário, apesar de ele não ser sobre isso, é preciso dizer no final da aula o quão fantástica é Clarice Lispector, e sem dizer o que ela diz, mas sim o nosso sentir, assim como a vontade de lê-la, ou... a vontade de filosofia. Ou de Coca-Cola.

6. Pelo que pude compreender, parte de seu trabalho iniciado a partir da temática "materialidades da comunicação" critica essa noção ocidental de que seria possível para o sujeito ter agência em 
relação às tecnologias criadas por ele. Nesse sentido, pergunto se o senhor acredita que o desenvolvimento técnico se autonomizou a ponto de ter uma lógica própria, de modo que falar em qualquer interferência ou teleologia humana é inútil ou mesmo ingenuidade.

O que seria o conteúdo da palavra "lógica" é difícil. Quer dizer, se você já pressupõe que, naquelas sequências, naquelas evoluções [tecnológicas], existe uma lógica... sendo de ciências humanas, você já fica muito hegeliana, não? Mas, sim, acredito que é um erro profundo achar que na história do homo sapiens as invenções estão sendo feitas segundo as necessidades. Para dar um exemplo muito claro, a imprensa teria sido muito útil já muito antes de 1450 . E a cultura ocidental teria sobrevivido mais 200 anos sem imprensa. Muitas vezes seria possível dizer, por exemplo, que era necessário inventar a energia nuclear. A energia nuclear foi, nesse sentido, talvez sim, talvez uma coisa completamente necessária, segundo a lógica da física... mas, ao mesmo tempo, trata-se da coisa mais desnecessária, a que mais arrisca a sobrevivência da espécie. E é horrível o fato de que certas invenções, uma vez que estão lá, não podemos esquecer, não podemos desfazer. Nesse sentido, a situação norte-coreana e toda a sua absurdidade é um bom exemplo. É até comparativamente barato desenvolver uma arma nuclear. Mas não se pode depois eliminar esse tipo de coisa. As pessoas na pedagogia sempre estão falando como se pudessem apagar a situação eletrônica. Não se pode apagar, é claro. Mas não é possível argumentar que a gente precisava de $e$-mail. Eu vivia muito feliz sem computador, sem e-mail. E, hoje em dia, tragicamente, sou escravo dele. Recebo muitos e me sinto na obrigação de responder. Nesse sentido, entendo que momentos históricos da existência humana vão interagindo com certos eventos tecnológicos que estão ocorrendo. Por exemplo, como eu falava há pouco, sobre aquele cruzamento entre universo de contingência e eliminação do espaço. Outro exemplo interessante para pensar: o primeiro programa de televisão surgiu na Alemanha nazista, em março de 1935. E eles escolheram o dia do nascimento de Goethe para televisioná-lo. E até os últimos anos da década de 1940, ninguém sabia o que fazer com a televisão. Os nazistas venderam os televisores por um preço muito baixo porque ninguém os queria, já que não havia programas. Então era a polícia que usava. Mas em geral não se sabia o que fazer com os televisores. De repente inventaram nos EUA aqueles programas de quiz shows e as séries de família. Então se aprendeu o que poderia ser feito. Isso prova que não existe uma sincronização entre a "evolução tecnológica", de um lado, e a história da cultura humana, de outro lado. 
7. Tenho uma curiosidade muito grande de saber como o senhor avalia o fato de que a sua presença em lugares distintos do globo pode ter afetado sua própria produção intelectual. Exemplo claro disso é a obra "Elogio da beleza atlética", na qual o senhor se reporta à tradição da Estética de maneira extremamente criativa para tratar o tema do esporte. E já há trinta anos o senhor mora e leciona nos Estados Unidos, que é um país famoso pela intensa cultura esportiva, inclusive no âmbito universitário. Também poderíamos citar sua relação com o Brasil, onde o senhor trabalhou, ainda que por curtos períodos de tempo, mas ao qual volta todo ano desde 1977, e o qual já apareceu em alguns dos seus textos (por exemplo, em sua análise de Machado de Assis). O senhor poderia comentar um pouco sobre isso?

De novo, eu não tive um programa para desenvolver isso. Mas uma boa definição de "cosmopolita" é uma pessoa que não se sente completamente em casa em país nenhum, em cidade nenhuma. Então eu adoraria ser cosmopolita nesse sentido. Eu me sinto muito à vontade e adoro estar aqui com você. Como você sabe, sei muito bem que sou gringo. Não no sentido negativo. É claro que é horrível você, depois de 1930 anos morando nos EUA, ainda ser reconhecido como estrangeiro pelo sotaque alemão. Eu, por exemplo, nunca estive numa high school jogando american football. Adoraria, mas nunca estive. Sou super patriótico e me sinto até orgulhoso do meu passaporte, apesar do Trump. Mas não sou completamente americano. Sou da Alemanha, mas não gosto nada, nunca gostei da Alemanha etc. Adoro o Brasil, mas não sou brasileiro. Só para abrir: acho que, de certa forma, tenho buscado ter raízes no Brasil. Raízes na Alemanha tenho, e não quero ter. E aqui, nos EUA, tenho raízes, porque já vivi aqui metade da minha vida etc. E acho que é uma condição importante. Nunca tive o programa de fazer as coisas desse modo. Acho que, se houve um impulso para isso, foi uma sorte ter nascido na Alemanha três anos depois de ter acabado a Segunda Guerra Mundial, não tanto pelas ruínas, não tanto pela destruição, ou pelo famoso milagre econômico alemão na Alemanha Ocidental, mas porque a minha geração (a mesma coisa com o Sloterdijk) se sentia com uma obrigação de adotar a responsabilidade por crimes de épocas em que nem vivíamos quando aconteceram. Nunca foi uma decisão. Ou, se foi uma decisão, foi uma boa decisão. Estou quase orgulhoso disso. Acho que é a coisa para se fazer. Mas cria uma relação com a sua pátria primária muito complicada. Eu me lembro da primeira vez, aos 16 anos, em que fui com a família da minha tia 
à França e gostei demais. Gostei mais por nenhuma outra razão senão pelo fato de que não era a Alemanha e que era muito diferente da Alemanha. Fiz o último ano do segundo grau em Paris. Isso aconteceu primeiro com a França, da qual continuo gostando muito, apesar de achar que hoje em dia não está num bom momento. Está culturalmente bem fraca. Talvez não só culturalmente. Já para me aproximar um pouco do Brasil, recordo que um dia Alexandre Pacheco ${ }^{8}$ me contatou e disse: "Você é tão generoso com os brasileiros. Você gosta dos brasileiros". Lamento, eu gosto sim dos brasileiros, mas porque eu gosto mesmo é de pessoas. Não tenho algo especial com os brasileiros. Gosto tanto dos argentinos como dos brasileiros. Assim como gosto de viajar e de estar em lugares diferentes. A questão é: de que maneira gosto de estar em lugares diferentes? Todo intelectual tem obrigação de dizer que não gosta de ser turista, é claro. Eu gosto de trabalhar num lugar. E, para mim, trabalhar num lugar é a melhor forma de conhecer o lugar, de fazer uma imersão. Por exemplo, agora em julho a gente vai pela primeira vez para a Nova Zelândia, o que é ótimo, porque em todo caso minha esposa está muito interessada na natureza de lá e tudo isso. Mas eu também darei um curso de uma semana. Gosto disso. A mesma coisa aconteceu com o Brasil. Eu nunca aprendi português formalmente. Nunca tive uma gramática ou dicionário. Escrevo muito pouco, ou mesmo não escrevo. Meu português é produto de uma aprendizagem de linguagem quase infantil. E foi graças a estar lá, dando aula, sobretudo no Rio. Em certo momento alguém me disse: "Mas o que você fala é portunhol. Poderia tentar falar português". Então eu nunca fui especialista de cultura brasileira, só que, ao longo dos anos, e, por causa da ressonância que tanto as minhas aulas como as minhas publicações tiveram no Brasil, o país foi se tornando super importante para mim. Não por casualidade, a presença na minha fala do colóquio brasileiro foi bastante massiva. ${ }^{9}$ Para deixar claro: adoro estar no Brasil, mas não é uma escolha. Se dissesse que o Brasil é meu país favorito, seria uma mentira. Eu

8 Professor do Departamento de História da Universidade Federal de Rondônia (UNIR), que estava fazendo pós-doutorado na Stanford University sob a supervisão do professor Gumbrecht, à época da entrevista.

9 Trata-se de outra alusão ao colóquio After 1967: Methods and Moods in Literary Studies, que contou com a participação de acadêmicos de diversas partes do mundo, inclusive algumas do Brasil. Participaram com apresentações Guilherme Foscolo (Universidade Federal do Sul da Bahia - UFSB), João Cezar de Castro Rocha (Universidade Estadual do Rio de Janeiro - UERJ), Ligia Diniz (Universidade de Brasília - UNB), Luiz Costa Lima (PUC - Pontifícia Universidade Católica-RJ), Marcelo Rangel (Universidade Federal de Ouro Preto - UFOP) e Otavio Leonidio Ribeiro (PUC-RJ). 
seria capaz de dizer isso, mas, basicamente, por alguma casualidade; eu estou mais no Rio do que em Buenos Aires, embora não possa dizer que goste mais do Rio que de Buenos Aires. São bem diferentes. No final das contas, a não decisão ocorre em função da repercussão. Tendo nascido no centro da Europa - porém mais do lado oriental, porque minha cidade natal fica a $140 \mathrm{~km}$ da fronteira com a República Tcheca -, nunca tinha estado lá. Por causa de traduções, recentemente, fui ao menos uma vez na Rússia, na Polônia etc. Devo admitir que, embora politicamente seja de muito mau gosto, adoro Moscou. É uma cidade muito como São Paulo. Não são cidades lindas. Mas têm um ritmo, uma agressividade, uma espécie de bliss, de que gosto muito. De repente poderia ser minha cidade favorita, mas não diria isso.

\section{O senhor considera haver diferenças marcantes - além, é claro, da diferença enorme de investimentos e recursos - entre a academia brasileira e outras academias que conheceu, como, por exemplo, a estadunidense ou a europeia?}

Finalmente uma pergunta para a qual tenho uma opinião bem formada. E não direi coisas lindas apenas para que você publique na revista, uma vez que já venho falando disso em sala de aula. Tipologicamente a situação universitária no Brasil, apesar de existirem exceções, como as PUCs e as privadas, é caracterizada por ter como espinha vertebral as públicas. E acho que esse sistema universitário é menos comparável ao francês e mais ao alemão. Porque o francês tem as grandes écoles em Paris que têm uma formação que o Brasil não tem. Acho que até faz falta. Mas na Alemanha e na Suíça há boas universidades. E acho também que é comparável em outro sentido. Posso dizer que nunca estive numa universidade federal no Brasil sem encontrar algum colega, ou mesmo vários colegas, ou algum doutorando, algum aluno interessante. Podem ser muitos, podem ser poucos, mas não posso lembrar de jamais ter ido a uma universidade federal no Brasil sem falar com pessoas ao menos competentes, e muitas vezes interessantes. E também ia fazer uma provocação de dizer que na Alemanha o sistema universitário é quase tão bom quanto o sistema que vocês têm hoje no Brasil. Mas isso precisamente impossibilita a emergência de universidades de ponta. O Brasil nunca vai ter uma Stanford ou Harvard. A Alemanha tampouco. Mas, claro, depende de uma política. O Estado não vai criar uma elite e talvez ele não deva criar uma elite. Talvez os impostos tampouco devam ser usados para criar uma elite. Mas eu acho 
que não há um ranking como se fosse uma liga de futebol. Nesse sentido, eu não tenho nenhum problema com a frase "o sistema das universidades federais no Brasil é um dos sistemas universitários públicos mais fortes do mundo". A Suiça é melhor, por exemplo. A Inglaterra é melhor. Mas eu não tenho certeza que a Alemanha seja melhor. Ao contrário.

O que estou falando é basicamente uma casualidade. Um país semelhante na América do Sul, mas diferente por ser menor, é o Chile. As universidades chilenas são boas. Tem umas católicas também boas. O resto é esquecível. E nunca vai ter uma universidade de ponta. Mas, se estamos falando especificamente das ciências humanas no Brasil, é uma questão diferente. Para mim, é quase natural que a filosofia seja o centro das ciências humanas. A filosofia não tem campo. Se um colega ou aluno das ciências humanas me diz que é historiador e não tem interesse na filosofia, eu tenho vontade de dizer: "Então você não deveria fazer ciências humanas". Não tem que ser filósofo, especialista. Mas tem que ter interesse. Acho que, no Brasil, por razões históricas óbvias, é diferente. Claramente a disciplina que influencia o jeito e o olhar acadêmico predominantes no Brasil é a antropologia. Isso está se desfazendo hoje, quase infelizmente. Mas a figura emblemática, o Levi-Strauss na USP, muito cedo iniciou na tradição brasileira um olhar. Eu diria que um cara como o João Cezar de Castro Rocha, apesar de seu doutoramento em Stanford, tem bastante disso também, isto é, um pouco da tradição de Oswald de Andrade, da antropofagia etc. Mas isso é quase único. Só no Brasil e talvez na Bolívia. Em segundo lugar, outra coisa menos única, mas que acho interessante, é que a crítica literária no Brasil fica mais perto da produção e da cena literária contemporânea que em outros países. Por exemplo, um cara como o meu ex-aluno, Italo Moriconi, que escreve coisas super interessantes, que é especialista na literatura contemporânea e que tem metade da sua vida profissional na UERJ e a outra metade, na cena literária brasileira. Ele faz parte disso e é muito bom professor por fazer parte disso. Isso, a propósito, é tão longe do que estou fazendo quanto é possível. Mas não porque eu não ache interessante. Só estou fazendo outra coisa. Eu adoro ler o Italo, e adoro falar com ele, porque ele tem um jeito intelectual diferente. Para falar quase objetivamente, tem sido muito produtivo ir ao Brasil ao menos duas vezes ao ano para coisas de trabalho. E eu acho que em parte tem a ver com essa diferença, com essa centralidade da antropologia.

\section{Uma questão possivelmente polêmica: percebendo a extensão e a erudição do seu trabalho, não posso deixar de me perguntar}


como ele absorveu ou reagiu às críticas à ideia de cânone literário, à ascensão dos estudos culturais e à expansão dos objetos de análise possíveis para a crítica literária e o comparatista. Vemos que na sua obra o senhor explora culturas e literaturas que normalmente são deixadas de lado pelo cânone ocidental, como a latino-americana ou a japonesa. Da mesma forma, também é possível dizer que o senhor se abre a questões da cultura popular, como o esporte ou a música de Janis Joplin. Gostaria de saber como o senhor escolhe seus objetos de análise. $O$ senhor acredita que definições como as existentes na língua inglesa de lowbrow, middlebrow e highbrow ${ }^{10}$ são funcionais e ainda devem ser usadas pelo crítico literário?

Comojásetornatradiçãona nossaconversadehoje, começarei respondendo genealogicamente. Vai ser uma surpresa, mas eu acho que, entre as culturas nacionais clássicas, dentre as quais a Alemanha sem dúvida se encontra, a que tem menos cânone é a Alemanha. Tem várias razões profundas. Mas uma razão do século XX é que a Alemanha tem pessoas ricas, mas não tem uma classe média, uma burguesia clássica. Nem falo de uma aristocracia. Devido às duas descontinuidades, a Primeira Guerra e a Segunda Guerra Mundiais, aquelas velhas famílias com uma boa biblioteca, onde os filhos leram os clássicos, quase não existem mais. Eu acho que até no Brasil existem mais que na Alemanha. Outra razão mais política é que existem três países germano-falantes com interesses de cânone diferentes. Musil é ainda mais importante na Áustria que na Alemanha, por exemplo. E o alemão não gosta de dizer o que estou dizendo, isto é, que Musil é mais importante que Thomas Mann. Para eles isso já é um problema. Porque é a mesma literatura. Não são separadas. Não existe literatura austríaca, suíça e alemã, já que se trata do mesmo espaço, das mesmas resenhas etc. Mas sobretudo isso é interessante porque, com a partição alemã, há 40 anos, em 49 precisamente, a parte oriental tentou estabelecer um cânone diferente e claramente socialista. E acreditando muito na importância daquele cânone. A Alemanha Ocidental já seguiu mais a tradição natural da Alemanha. Mas até o Goethe não é clássico muito estabelecido. Há pessoas extremamente cultas na Alemanha que acham Goethe uma merda. Pensam que não deveriam nomear as escolhas de leituras de ensino médio segundo Goethe. Nesse sentido, não existe nenhum clássico alemão que seja indiscutível. Devo dizer que claramente essa ausência de

1o Baixa, média e alta cultura, respectivamente. 
cânone me formou, para falar paradoxalmente. Em segundo lugar, eu saí de uma família de novos ricos. Meus pais eram médicos, ambos cirurgiões, e saíram de famílias sem cultura nenhuma. Os livros na minha casa eram de urologia. Um livro, Manual de sexualidade humana, era meu favorito quando meus pais estavam ausentes. E minha mãe recebeu uma edição completa do Schiller quando da sua formatura de ensino médio, mas nunca tinha lido nada. Sempre foi muito boa aluna, mas não teve isso. Nasceu numa família muito típica da Alemanha Ocidental, depois da guerra. Ganhava muito dinheiro e me motivava a comprar livros, porque achava importante. Mas meu pai não me dizia "você tem que ler Thomas Mann”. E, finalmente, geracionalmente, sou da geração de 1968, que é muito anticânone, muito antiautoridade. Isso explica de uma certa forma aquela situação caótica no meu cânone. Estou fazendo qualquer coisa de que gosto. Quer dizer, gosto das pessoas e gosto dos livros. Uma coisa que você disse tem a ver com a minha maneira de viver essa profissão, que estou acabando hoje praticamente. Acho que uma das vantagens fantásticas dessa profissão é que, se você está usando os potenciais, as possibilidades que ela oferece, é possível fazer muita coisa. Eu diria que, no meu caso, 80\% do tempo que estou investindo para ganhar um salário estou fazendo coisas que gosto de fazer. Muitos colegas não o fazem, porque perguntam o que devem fazer e qual a sua obrigação política ou institucional. Eu faço sempre o que gosto de fazer. Os poucos cursos que tenho dado são coisas que eu queria fazer. Imagine. Bliss. Acho interessante fazer isso. Quando eu fiz dois anos atrás um curso sobre Marx, foi porque eu quis relê-lo e descobri um autor completamente diferente do Marx da minha juventude. Se você se permite essa liberdade, existem duas opções. Você pode fazer como o Costa Lima, por exemplo. Estou exagerando um pouco, mas ele toma a liberdade de trabalhar toda a vida dele sobre um tema. A propósito, eu acho Costa Lima um dos grandes intelectuais de ciências humanas hoje. Nasceu em Pernambuco. Se ele tivesse nascido em Yale ou Paris, seria mais reconhecido. É uma amizade sempre um pouco frágil, porque muitas vezes discrepamos politicamente, mas o adoro e adoro sua obra. Quer dizer, o Costa Lima, assim como o seu muito amigo Wolfgang Iser, aquele do Act of Reading, basicamente passará a vida trabalhando sobre uma única coisa. Já eu sou o caso contrário. Nesse sentido, tenho uma identificação muito forte com Diderot. Não tenho centro. Seria até muito difícil para mim dizer qual o meu centro no meu cânone. O livro que mais definiu a minha concepção foi provavelmente Produção de presença. 
Muitas vezes as pessoas me perguntam "O que posso ler para conhecer sua obra?”. Não sei. Não tenho certeza. Talvez alguma coisa sobre futebol americano. Ou alguma coisa sobre Janis Joplin. E, para concluir já, isso também vai passando... Quer dizer, são coisas que estou adorando num momento, e menos no outro. Como vou dizer de uma forma aceitável? Eu não sou naturalmente uma pessoa fidelíssima. Faço um esforço por ser fidelíssimo. O meu primeiro pai político na Espanha dizia o seguinte: "He vivido mucho". Gostaria de dizer que tenho vivido muito, que tenho feito muitas coisas diferentes. Sou mais pela pluralidade. Até acho que quatro crianças não são o suficiente. É suficiente financeiramente! Eu na verdade queria ter mais de quatro.

10. Um dos aspectos admiráveis da sua trajetória é a interdisciplinaridade que observamos nas suas obras. Se isso já é incomum em alguns contextos, eu diria que no Brasil causa enorme espanto, porque nós temos uma cultura acadêmica que, salvo raras exceções, apesar de frequentementequererse dizer interdisciplinar, é muito dividida por áreas de pesquisa e departamentos. Mesmo quando tratamos somente da grande área "humanidades", é difícil de enxergar diálogos entre as várias subáreas. Grosso modo, poderíamos dizer como exemplo que a prioridade do historiador é, frequentemente, a busca pela sincronicidade ou pelo processo histórico, enquanto o teórico da literatura e o filósofo buscam conceitos e definições mais abrangentes e generalizantes. E essas duas práticas frequentemente não se comunicam no Brasil. Soma-se a isso, na minha modesta impressão, o fato de que ainda temos uma tendência, possivelmente herdada da colonização, de desprezar nossas capacidades de participar de um diálogo acadêmico internacional. Nesse sentido, a academia brasileira parece ter enorme receio de fomentar qualquer pesquisa que possa parecer iconoclasta. Na sua disciplina sobre Literature and Bliss, o senhor parte na primeira aula da Literatura Grega Antiga e, após percorrer a História da Literatura ao longo do curso, finaliza com uma discussão sobre autores tão diversos quanto Beckett, Pynchon e Clarice Lispector (isso sem falar na discussão sobre a possibilidade de bliss no Vale do Silício!). Embora essa amplidão seja em tese o ideal de qualquer comparatista, tenho que confessar com admiração que nunca vi nos meus anos de formação no Brasil ementa tão ousada. Embora eu tenha a impressão de que não é 


\section{possível ensinar criatividade, gostaria apenas de perguntar como o senhor vê ser possível construir um ambiente acadêmico mais interdisciplinar e com pesquisas mais ousadas e ambiciosas?}

Em primeirolugar, não posso discordar, porquevocêconhece infinitamente melhor a situação universitária no Brasil, sobretudo interiormente. Você tem sofrido pessoalmente com um sistema universitário. Mas eu não tenho a impressão de que a disciplinaridade seja mais rígida no Brasil que em qualquer outro lugar. Acho que é normal. Também acho que não se deve demonizar isso, porque instituições precisam de estruturas. $\mathrm{O}$ que acho uma invenção genial e que na verdade só existe em Oxbridge, mas não no sistema inglês como um todo, e também nos Estados Unidos, é o college. Não estou defendendo que se faça college para sempre e para a vida toda... Mas, sim, o aspecto interdisciplinar. É preciso fazer quatro anos para ser uma pessoa culta. Desde matemática, passando pelas ciências clássicas, engenharia, até filosofia. É maravilhoso. Felizmente existe nos EUA e existe em Oxbridge, e acho fantástico. Não tem no Brasil. Na Alemanha tampouco, embora agora estivessem tentando implementar. Acho maravilhoso que um estudante de 19 anos possa ter essa complexidade propiciada pela interdisciplinaridade. Segundo, e talvez seja a resposta melhor: não quero demonizar a disciplinaridade, as fronteiras entre disciplinas, porque acho que é uma necessidade institucional, por exemplo, para a promoção. Você deve declarar que é crítica, teórica literária, para que as pessoas possam julgar se você merece ser promovido. Se merece o seu doutoramento, o seu emprego. E o mesmo ocorre com alunos. É chato. É desinteressante. Mas também é assim e não se pode eliminar facilmente. Mas acho que qualquer problema interessante, e até problema não interessante, é interdisciplinar. Isto é, quase todos os problemas são naturalmente interdisciplinares. Muitas vezes, se você começa um trabalho no contexto de uma disciplina, o problema inicial do trabalho "purifica" um fenômeno dos aspectos que não são da disciplina. Por exemplo, se você fala do erotismo na crítica literária, libera o erotismo de todo fascínio sexual. Estou falando um pouco ironicamente. Então, nesse sentido, a minha "interdisciplinaridade" é também bastante natural, bastante ingênua. Tive sorte. Me davam permissão de fazer coisas que achava interessantes. Eu fiz como doutoramento um livro de que não gosto muito, sobre hipérbole na épica medieval francesa e espanhola. E logo depois fiz como habilitação um segundo livro, sobre funções da retórica parlamentar na revolução francesa, traduzido no Brasil pela 
UFMG. E as pessoas comentavam: "Mas não é bem de linguística"; "Não é bem de história”; "Não é de literatura”... tanto faz. Consegui me qualificar etc. E, para concluir, logo, depois de certo momento, você tem certa autoridade. É verdade que, no começo da carreira, você não pode se permitir ser tão "interdisciplinar" quanto sou agora. Se eu tivesse começado a escrever seriamente de esportes quando tinha, não sei, 25 anos, teria sido ruim para a minha carreira. Trata-se da sabedoria de um velho. Mas é um pouco saber em cada situação o que pode funcionar. Agora, para realmente concluir, odeio o conceito "interdisciplinaridade" nas bandeiras dos intelectuais, porque é uma heurística falsa, uma vez que qualquer problema interessante já é interdisciplinar. Uma pessoa só disciplinar não consegue ser um intelectual. Acho que essa é uma frase boa para concluir.

11. De visita a Stanford, pude acompanhar sua atuação no Philosophical Reading Group, que o senhor comanda junto com o professor Robert Pogue Harrison, e também a última disciplina que o senhor deu antes da aposentadoria de Stanford, sobre Literature and Bliss. Nessas horas, um pesquisador é impelido a fazer uma espécie de retrospectiva da carreira. E, ao mesmo tempo, observando sua vitalidade, ficamos curiosos para saber se a discussão na disciplina irá se tornar um novo livro. $O$ senhor poderia comentar um pouco sobre seus projetos de pesquisa e publicação que vêm por aí?

Eu estou levando tempo demais para terminar um livro que está no momento literalmente meio acabado. Tenho 3 e meio de 8 capítulos. $\mathrm{O}$ título vai ser "Prosa do mundo: Diderot, Goya, Lichtenberg e Mozart". E "prosa do mundo" é uma citação do Hegel. Porque Diderot é o terceiro autor mais citado na obra de Hegel, mas ele não sabe o que fazer com Diderot. Não tem lugar, no sistema hegeliano, para Diderot. E o argumento do livro não é que Diderot faz resistência a Hegel. Quero argumentar que existe uma configuração epistemológica saindo do século XVIII que não tem a ver com o Iluminismo. Não no sentido de que seja pior, ou de que seja de direita. Apenas uma configuração diferente e que continuou a se desenvolver na cultura ocidental. Eu diria que Nietzsche, por exemplo, faz parte disso. Assim como Heidegger. Mas essa configuração não tem sido reprimida, e sim preferida. E talvez hoje em dia, para usar uma frase muito hegeliana, o seu momento tenha chegado. 
Uma coisa que não é evidente e que estou fazendo recentemente é ser advisor, conselheiro, para o desenvolvimento de ciências humanas. Porque ninguém sabe o que fazer com ciências humanas. E as ciências humanas me interessam, assim como as universidades. Mas estou fazendo sobretudo porque, comparativamente, me pagam muito bem para isso. $\mathrm{E}$ há outro livro que farei com certeza. Para falar de uma forma provocadora, é um livro quase com a intenção de reabilitar intelectualmente as massas. $\mathrm{Ou}$, como falam, os corpos místicos. Porque, quando se fala das massas na cultura ocidental, é sempre negativo. O indivíduo é visto como maravilhoso, heroico etc. As massas sempre são o contrário. O socialismo fazia um esforço de reabilitar as massas, mas teve um resultado chato. Tampouco gostaria de defender as massas como solidariedade. Tenho fascínio por esse conceito teológico, “corpo místico”, que consiste em um conceito de comunidade que inclui o corpo. E, sem dúvida, a associação primeira é sempre com as assembleias do partido nazista, o que não deixa de ser uma relação verdadeira. É verdade também que se pode relacionar com o que aconteceu em São Januário, aquele acidente horrível com o Vasco da Gama, anos atrás. Uma torcida se movendo muito quebrou uma estrutura do estádio, o que feriu mais de uma centena de pessoas. Mas ao mesmo tempo eu em primeiro lugar adoro fazer parte de uma massa. Adoro estar na arquibancada do Flamengo, no Rio de Janeiro, no Maracanã. Até, apesar de nunca ir, na missa do Papa, por exemplo. Gosto da prática, de fazer parte de uma massa. E isso tem quase um aspecto redentor para mim. E também há uma pergunta interessante a se fazer: existe uma legitimidade política nisso? Existem dois cantões muito pequenos na Suíça onde os votos têm que se fazer em presença real do povo. Mas não quero fazer reabilitação no sentido de dizer que é maravilhoso. Mas sim nesse sentido de que corpos místicos são perigosos. Tem uma coisa deliciosa neles. Quase bliss.

A Reclam quer fazer dois livros meus. Dentre os quais, uma coletânea de artigos. Se há um cânone alemão, é a Reclam. São esses livrinhos amarelos de clássicos da cultura alemã. Então isso é uma canonização enorme na Alemanha.

Além disso, tenho pensado em escrever um livro talvez de 100 páginas sobre bliss. Mas esse tem que ser um pequeno ensaio. Infelizmente, não sou Kant em muitos sentidos. A razão da escolha do tema para minha última disciplina em Stanford foi, na verdade, duas. O título é basicamente chato, pois parece ser a representação do bliss na literatura. Mas fiz um 
seminário semelhante, com uma pergunta semelhante, Literature and Death [literatura e morte], que funcionou muito bem. Eu queria ter para o meu último seminário um título afirmativo, positivo. Então, bliss. É um conceito precioso, que só existe em inglês. Saiu tão bem a mise au point, mas tão surpreendentemente coerente, que acho que é quase um projeto concreto. E acho que a gente tem uma série de distinções boas e interessantes, além de insights novos que se pode articular. Mas, se você faz um livro muito extenso, perde o charme da coisa. É muito mais interessante uma sugestão. É uma matéria sobre a qual não existe nada e que a gente coletivamente descobriu. O problema ético disso, e falo entre aspas, é que isso é tão maravilhosamente um produto coletivo que sinto ser um problema escrever um livro sob meu nome. E também gostaria de fazer, também como resposta à pergunta anterior, uma fenomenologia da voz. Fenomenologia muito no sentido não husserliano. Não seria uma sistematização, mas um pouco como aquele ensaio sobre a Janis Joplin. Por exemplo, uma voz que me fascina é a da cantora britânica Adele. É muito difícil de dizer porque essa voz é tão boa. Outro fenômeno: Elvis Presley. Eu escutava Elvis Presley na minha infância, quando tinha 6 ou 7 anos. Estava vivendo na Alemanha sob ocupação americana e todas as estações de rádio eram americanas. E eu sabia cantar várias canções em inglês mesmo sem saber inglês. Sua voz foi uma das vozes do século XX. Esse então é o livro que gostaria de fazer. E até poderia imaginar ainda outro livro sobre cantores, trovadores etc.

\section{E o Bob Dylan ganhou um prêmio Nobel...}

Isso foi interessante. Eu insisto que foi merecido, mas não tanto pela lírica. Sevocê extrai a lírica dele, das canções, não é ruim. Mas éa performance que é realmente grande. $\mathrm{O}$ livro dos corpos místicos poderia incluir também uma análise das torcidas. A humanidade não precisa desses livros para sobreviver. Tenho muita certeza. Mas parte da decisão de me aposentar é que é uma economia de tempo diferente. E eu gostaria de escrever vários desses livros antes de cruzar para o outro lado. 